\title{
The Mean Annual Loss of Life during Earthquakes
}

\author{
By Dr. Charles Davison
}

$I^{\mathrm{T}}$ $\mathrm{T}$ is always difficult to make an accurate estimate of the number of lives lost during a great earthquake, and impossible in such disasters as those of Lisbon in 1755 and Messina in 1908. For Lisbon alone, the estimates vary between 30,000 and 70,000 ; but the bodies were removed from the city in masses without being counted. In the Messina earthquake, the first estimates gave 150,000 as the number of persons killed. A later report reduces the figure to 82,000 , but, as it includes more than 32,000 "presumed killed", the real number may be about 50,000 . In the great Japanese earthquake of 1923 , there is the same uncertainty. According to the official estimates, 99,331 persons are known to have lost their lives, but there were also 43,476 reported as missing. In all cases in which the figures differ widely, the mean of the greatest and least is taken in the estimate that follows.

In an attempt to determine the average annual loss of life from earthquakes, it is necessary to include the earthquakes that occurred during a considerable interval. If this were not done, the effect of a small number of losses so great as that of the Japanese earthquake of 1923 might unduly distort the average. In that here given, the earthquakes of the two centuries 1735-1934 are taken, with the exception of the Calcutta earthquake of 1737, for which the report of 300,000 persons killed seems doubtful. The well-known Milne scale of intensity for destructive earthquakes is used, though earthquakes of the lowest degree are omitted, as they contribute but slightly to the loss of life.

During the two centuries mentioned, the total number of deaths in 135 earthquakes of the third degree of intensity in the whole world was $1,044,606$, and in 61 of the second degree 2,125 , leading to averages of 7,738 and 35 per earthquake. In the last century (1800-99) covered by Milne's catalogue of destructive earthquakes, there were 360 and 510 earthquakes of the two intensities. At the above rates, the total number of deaths per century would be 2,785,680 and 17,850 , giving 28,035 as the average loss per year.

The average annual rates obtained in the same way for certain important earthquake districts may be given. They are as follows: 13,862 in China, 7,980 in Colombia and Ecuador, 2,240 in Japan, 1,006 in Italy, 991 in Central America, 715 in India, 586 in Persia, 550 in Asia Minor, 99 in Greece, 35 in the Philippines, 29 in Formosa, and 6 in the United States. In addition to the above regions, there is a number of others, such as Spain, Portugal, Venezuela, Algeria, etc., in which the numbers of earthquakes with known losses of life are too small to give satisfactory results separately. Grouping them together as a single district, the corresponding average number of lives lost per year is 2,380. The sum of all the above numbers is 30,479 .

Thus, remembering the uncertainty of some of the estimates on which we have to depend, it would seem that the average number of lives lost every year in the earthquakes of the whole world is about 28,000-30,000. Of the two figures, the smaller is probably the more accurate, because the larger the region, the less will be the disturbing effect of the most destructive earthquakes.

\section{Obituary}

Vice-Admiral H. B. T. Somerville, C.M.G. 7 HE tragic death on March 24 of Vice-Admiral H. B. T. Somerville has removed from the world one who was imbued with the spirit of service and who, throughout his whole life, set an example of steadfast endeavour in all the duties which he was called upon to perform.

Boyle Somerville was blessed with good health, a strong sense of humour, a good voice, all the charming characteristics of the best type of Irishman, and won the friendship of all who knew him. Of his earliest years in the Navy the writer has no personal know. ledge, but his work as a surveyor remains, and it was a source of great satisfaction to him to know that his labours in so many parts of the world would continue to be of use and benefit to his fellow-seamen. To give something useful to the world, something which should endure for all time, is perhaps a normal 
hope of all pioneers, and an insight of the untiring efforts and application necessary to the accomplishment of a modern detailed survey is given in his book "The Chart Makers" which, humorous though it is in many places, shows how arduous is the task of the surveyor and how painstaking his investigations.

In 1889, Somerville was appointed to the Surveying Ship Dart and served in her and in the Penguin in Australasian waters until 1896 ; after a short period of service in the Hydrographic Department, Admiralty, he joined the Egeria, and in that ship he proceeded to British Columbia, carrying out surveying work in the Straits of Magellan en route. During the latter part of the commission he became first lieutenant, and was in 1900 appointed first lieutenant of the Triton in home waters. He became commander in 1901 and was next appointed to take charge of special tidal observations in the Channel Islands. In 1903 , he was ordered to undertake special surveys in the Persian Gulf, for which he received the appreciation of the Lords of the Admiralty. In the early part of 1904 he was selected to take command of the Sealark to carry out surveys in the Mediterranean and East Indies; it was during his time in the Sealark that he was instructed to collaborate with the Percy Sladen Research Expedition, in the work of which he was already so interested. Returning home to England at the end of 1907, he was placed in charge of the West Coast of England Survey, and in 1912 took command of the Research in home waters, in which ship he was serving on the outbreak of war in 1914.

During the War, Somerville, who had been promoted to captain in 1908, was in command of H.M. Ships Victorian, Amphitrite, King Alfred and Devonshire in the 10th Cruiser Squadron. He was promoted to Rear-Admiral in 1919 and to ViceAdmiral (Retired) in 1925.

His last work in the Hydrographic Department was the compilation of "Ocean Passages of the World", and he served as chairman of a Tidal Com. mittee in 1923.

Admiral Somerville was interested in a great variety of subjects, and whilst in the Pacific Islands collaborated with the late Commander S. C. Weigall, R.N., in compiling vocabularies of dialects of some of the Polynesian islands; he also turned his mind to the improvement of sounding appliances, and the Somerville gear, which was a great advance on older methods of sounding, is still used in the survey . ing service. The last years of his life were devoted to literary work chiefly connected with the South Seas, where so much of his early life was spent. In 1934, he published "Commodore Anson's Voyage into the South Seas and Round the World", in which he used his knowledge of those waters to rewrite Walter's classic, embodying at the same time the results of his researches in the Admiralty records of the period. At the time of his death he was engaged on a similar modernised version of William Mariner's "Account of the Natives of the Tonga Islands", and had already collected a considerable amount of unpublished material not known to Dr. Martin, who published the original book in 1817 .

\section{Mr. C. A. W. Monckton}

WE regret to record the death, which took place on March 1 in London at the age of sixty-three years, of Mr. C. A. W. Monckton, explorer and formerly administrative official in Papua.

Charles Arthur Whitmore Monckton was born in New Zealand in 1872 and went to New Guinea in 1895, when Sir William MacGregor was Lieutenant. Governor. In 1898 he entered the public service as resident magistrate at Samarai. The administration of the country under British rule was then in its earliest stages of organisation, and Monckton's duties were largely the pursuit of raiding parties, who constantly attacked the white miners within his jurisdiction, which covered the north-eastern area of the island, not previously administered, and of which he was the first resident magistrate. In 1903 he was also given the Northern Division, which was in a state of disorder.

In 1906, when in pursuit of previously unvisited tribes, some of whose members had raided a miners' camp and murdered some of its occupants, Monckton made the first ascent of Mount Albert Edward $(13,320 \mathrm{ft}$.) under the fire of hostile bowmen, and mapped the country from it. A more strenuous expedition of the same year to the Wasia River in search of gold and to ascertain how far the river lay in British territory encountered terrible hardships and ended in disaster, for which Monckton was criticised by the authorities. In September 1906, New Guinea had come under the Australian Common. wealth; and Monckton, with characteristicimpetuosity, resigned and retired to England, where he lived for the remainder of his life.

A pioneer in administration, Monckton was one of the first to recognise that the qualities which lead a native to transgress the white code by adherence to tribal custom, such as raiding and head-hunting, might be turmed into useful channels. He invariably recruited his very efficient police from such criminals. $\mathrm{He}$ published three books in which a great gift of humour was used to advantage in displaying a keen appreciation of native character, while at the same time recording data of no little value relating to tribes at that time unknown. His first book, "Some Experiences of a New Guinea Resident Magistrate", appeared in 1920 and was received with acclamation by the critics. It was followed by "Last Days in New Guinea", published in 1922, and "New Guinea Recollections" in 1934.

WE regret to announce the following deaths :

Mr. James Whitehead, K.C., fellow of the Imperial College of Science and Technology, who was a leading authority on Patent law, especially in its applications to technology, on April 3, aged fifty-eight years.

Dr. W. A. Parr, president of the British Astro. nomical Association in 1932-34, on April 2.

Prof. J. Stoklasa, director of the State Institute of Research in Plant Products, Prague, on April 4, aged seventy-six years. 